\title{
AGREEMENTS FOR SALE TO CORPORATIONS - THE REMEDY OF EXTRA-JUDICIAL DETERMINATION* UPDATE 1983
}

\author{
FRANCIS C.R. PRICE**
}

\begin{abstract}
The decision in City of Edmonton v. A. \& M. Developments Ltd. has provided the spring board to a number of actions by vendors seeking judicial confirmation of their exercise of a power of extra-judicial determination. The Alberta decisions since then have consistently confirmed the availability of such a remedy. However, as the cases come before the Courts, a number of problems have arisen, not all of which have been resolved in a consistent manner. In recent cases a number of preliminary problems or objections have been raised that the Courts must deal with before coming to the question of determination. In this article, the author reviews some of those problems and the developments made by the Courts in this area since 1981.
\end{abstract}

\section{PROCEDURE TO BE FOLLOWED}

\section{A. STATEMENT OF CLAIM}

There is no doubt that relief may be sought from the Court in a normal action commenced by way of a statement of claim. Indeed, if the vendor brings action for specific performance and judicial cancellation, he will have to commence action by statement of claim. ${ }^{1}$ If the vendor has effected an extra-judicial determination and seeks judicial confirmation of his action, it is essential that his statement of claim accurately reflect what has happened. Thus, use of the statement of claim in form Q.14 of the Rules of Court should be avoided. Many of its provisions, while appropriate to a specific performance action, are quite inconsistent with an action for a declaration that the agreement has already been determined and may land the draftsman in the "proverbial hot water"."

In the event there is no statement of defence or demand of notice filed, the vendor can presumably move, at the earliest, after fifteen (15) days have elapsed from service, for the requested declaration, usually on notice to the defendants, subsequent encumbrancers and to all who may be affected.

If a statement of defence is filed, the plaintiff may apply for summary judgment under R.159, on the ground that there is really no defence, or that the defence filed is a "sham". ${ }^{3}$ The question at issue must be beyond doubt. ${ }^{4}$ If there exists a triable issue to be resolved on the facts, then

* See the previous article by the same author in (1981) 19 Alta. L. Rev. 192.

** LL.B. (Hons.) (Melb.), LL.M. (Alta.), partner with the firm of Reynolds, Mirth \& Cote, Barristers and Solicitors, Edmonton, Alberta.

1. Rule 685.

2. Vladimer Holdings Co. Ltd. v. 203136 Alberta Ltd. (1982) 39 A.R. 104 (Funduk M.C.). Conversely, some of its provisions may be inappropriate to an action for specific performance, if they purport to determine the agreement. Clauses 7 and 8 in Form Q 14 (Statement of Claim) which are repeated in the Affidavit of Default (Form Q 15, clauses 8 and 9) talk of determination of the agreement "by these proceedings" - quite inaccurate in a specific performance action. See the comments of Quinn, M.C. in North West Trust Co. v. M.C.C. Development Ltd., unreported, 18 March 1983, Q.B. 8203 03823 , where the Master held that notwithstanding the insertion of these clauses in the Affidavit, the circumstances of the case indicated that the Vendor was actually pursuing a specific performance action.

3. Id. at 153 .

4. Pacific Western Airlines v. Gauthier (1977) 2 Alta. L.R. (2d) 52 at 54 (S.C.A.D.). 
summary judgment should not be granted. ${ }^{5}$ If, however, the Court can say to the defendant, "You have no defence in law", then summary judgment may be granted. ${ }^{6}$

\section{B. ORIGINATING NOTICE}

The alternative to an action commenced by statement of claim is to bring the matter before the Court by originating notice, pursuant to part 33 of the Rules of Court. Rule 410 sets out those circumstances in which matters may be brought before the Court by way of originating notice. Three of the clauses are applicable to the case where a vendor seeks a declaration of the validity of his extra-judicial determination of the agreement for sale.

\section{R.410(c)(i): Proceedings relating to land for the declaration of a beneficial interest in or charge upon land and of the character and extent thereof}

Upon the execution of an agreement for sale, the purchaser obtains a beneficial or equitable interest in the lands to the extent equity will decree specific performance. ${ }^{7}$ The vendor has a legal, as opposed to equitable, interest and a right to receive the payments due under the contract. Determination of the agreement for sale pursuant to the terms of the contract has the effect of vesting the purchaser's beneficial interest in the land back in the vendor, and the vendor then seeks confirmation of this beneficial interest in the land by way of a declaration of the Court. ${ }^{8}$ The "extent" of that beneficial interest includes, of course, a title free of any interest of the purchaser.

The procedure to be followed in pursuing such relief was questioned in the case of Genstar Limited v. Bestlands Development (Alberta) Ltd..$^{9}$ In that case, the applicant sought to enforce its rights by way of originating notice, asking for: (a) a Declaration that the applicant was the beneficial owner of the land in question; and (b) an Order directing the Registrar of the North Alberta Land Registration District to cancel the various certificates of title and issue new certificates of title in the name of the applicant.

The applicant sought to enforce its rights under an agreement for sale wherein it was the vendor, and relied in part upon R.410(c).

\section{Crossley J. stated:}

Certainly in our jurisdiction, the normal proceeding for the vendor is to seek specific performance of the agreement for sale against the purchaser and upon default, cancellation of the agreement for sale of land and sale of land or under certain circumstances to obtain title back. But in Alberta it certainly has been accepted for some time that due to the form of order nisi, form Q14, the court need not order specific performance of the agreement for sale but rather may declare the amount owing and direct sale or cancellation if the amount is not paid within a prescribed period. This is set forth in the case of Renner v. Racz [1972] 1 W.W.R. 109 at 112 (Alberta C.A.). Pursuant to the Alberta Rules of Court, the proceeding is within the meaning of foreclosure and used in Part 49 (Rule 663) and must be brought by a statement of claim (Rule 685). The proceeding cannot be brought by an originating notice of motion; furthermore, to allow the proceedings to be brought

5. Scandinavian A merican Nat. Bank v. Shuman [1917] 3 W.W.R. 745 at 746 (Alta. A.D.).

6. Id.

7. In re Church [1923] 3 W.W.R. 405, 409 (S.C.C.); Howard v. Miller [1915] A.C. 318 at 326 (P.C.).

8. The Court can make binding declarations of right, whether or not other relief is claimed: Judicature Act, R.S.A. 1980, c. J-1, s.11.

9. Unreported, November 1980, Q.B. 8003-13427, Crossley J.; revd. 21 January 1982, Appeal No. 14436. 
under Rule 410 would seem totally inappropriate given the extensive requirements as to foreclosure imposed under the Rules of Court and by common law (see Rule 686 and following).

An appeal was taken from the judgement of Crossley J. and on January 21,1982 , the Court of Appeal (without written reasons) allowed the appeal and granted the appellant (applicant) the relief sought in its originating notice, namely the declaration of beneficial ownership and the Order to the Registrar. In so doing, it is submitted that the Court of Appeal must have approved the bringing of such an application by way of originating notice, since this was the only ground discussed by Crossley J. in his written reasons on the initial application.

2. R. 410(a): Proceedings to recover possession of land.

That it is proper to bring proceedings to recover possession of land following cancellation by notice pursuant to the terms of agreement is supported by the authority of Smith v. Reuber, ${ }^{10}$ where Jackson D.C.J. made such an Order upon application by way of originating notice, under the legislation in existence prior to 1939. It should be noted that in Rose v. Wait, ${ }^{11}$ O'Connor J. refused such relief upon application by way of originating notice. However, this refusal was because of the 1939 amendment to The Judicature Act, which required that the matter proceed through the Court by way of advertising and judicial sale. ${ }^{12} \mathrm{O}$ Connor J. also referred to Green v. Longh $i,{ }^{13}$ where an Order for possession was made on originating notice, although the reasons for judgment were not published. Again, this application pre-dated the amendments to The Judicature Act in 1939.

As a result of the exception in the case of corporate purchasers, which was added to The Judicature Act in $1964,{ }^{14}$ the law relating to agreements for sale to corporate purchasers is now the same as it was prior to 1939, so cases such as Smith v. Reuber ${ }^{15}$ once again have application.

The Court of Appeal appears to have approved the procedure seeking such relief by way of originating notice in Genstar Limited v. Bestlands Development (Alberta) Ltd. ${ }^{16}$

3. R. 410(e): Proceedings for the determination of any question where there are no material facts in dispute and the rights of the parties depend upon the construction of

(i) an instrument. . .

and for a declaration of the rights of the persons interested.

The scope of R. 410(e) was reviewed by the Appellate Division of the Supreme Court of Alberta in Harvie v. Calgary Regional Planning Commission. ${ }^{17}$ In that case, the Calgary Regional Planning Commission had approved a subdivision application without giving notice of the application to a neighbouring landowner. The appellant sought a declaration that the decision of the Regional Planning Commission was void. At trial, it

10. [1941] 1 W.W.R. 119 (Alta. S.C.).

11. [1941] 1 W.W.R. 634 (Alta. S.C.).

12. S.A. 1939, c.85. For background history, see (1981) 19 Alta. L. Rev. 192.

13. (1914) 7 W.W.R. 924 (Alta. S.C.).

14. S.A. 1964, c.40, s.4.

15. Supra n.10.

16. Supra n.9, where Rule $410(a)$ was also relied on by the applicant.

17. (1978) 12 A.R. 505, 519 ff. 
was held that such declaration was not a declaration of the rights of the parties to the litigation. On appeal, Clement J.A. held: ${ }^{18}$

On the first point, I am, with respect, of opinion that the learned trial judge took too narrow a view. The question for determination was whether on the proper construction of the Act and the Subdivision and Transfer Regulation, the decision was void. It is not essential to the jurisdiction of the Court that consequential relief be also claimed: The Judicature Act, R.S.A. 1970, c. 193, s.32(p) [now s.11 of the Judicature Act, R.S.A. 1980, c. J-1]. If the circumstances support the conclusion in law that the decision was void, and if Glenbow Ranching had legally recognizable interests which were significantly affected, then in my opinion, Glenbow Ranching has a right as against the respondent Commission to have it so declared.

In the course of reaching such conclusion, the Court would also have to declare as against the Commission a breach of natural justice or, either by itself or additionally, an excess of jurisdiction

...

The point is raised as a technicality to defeat consideration of the substance and should not be sustained. I would allow the appeal on this point.

In the Harvie case, it was also asserted that the contention of the appellants that the decision of the Planning Commission was based on irrelevant considerations raised a dispute on material facts so that R. 410(e) was not available. The Court reviewed the facts which gave rise to the allegations of irrelevant considerations and dealt with this submission by finding: ${ }^{19}$

What is involved here in reality is not a dispute over material facts, but what reasonable inference is to be drawn from the undisputed facts in the record. The minutes are prima facie evidence of what transpired at the meeting, and the respondent has not added to the record any facts, either of a contentious nature or at all, which could influence the inference to be drawn. I am of the opinion that the Rule is directed to material facts of a primary nature, not to inferences that might reasonably be drawn by the Court from undisputed primary facts.

Rule 410(e) was more recently considered by Veit J. in Canada Trust Company v. Lagrimas Estates Ltd., ${ }^{20}$ a case where the applicant (vendor) sought a declaration that the agreement for sale had been cancelled and that the deposit paid be forfeited to the applicant. In granting the application, her Ladyship quoted from In Re Lloyd Estate:21

... the procedure of hearing disputes by way of originating motion was for the purpose of simplifying the administration of justice and court procedure and to lessen the cost of litigation.

In Tymo v. Wild Rose Properties Ltd, ${ }^{22}$ it was argued by the purchaser before Purvis J. that proceedings should have been commenced by statement of claim and not originating notice. However, his Lordship granted the declaration sought by the applicants (vendors) that the agreement for sale had been determined and ordered that the caveat be removed and possession granted. His Lordship was, however, not prepared to decide on the motion the question of relief from forfeiture of the $\$ 515,000.00$ paid under the agreement and directed a trial of that issue.

It is suggested that where there are no matters in dispute, (i.e. where default, proper notice, documents, etc. are all conceded) proceedings may be commenced by originating notice and the appropriate declaration obtained. Where affidavit evidence of insufficient value of the land and of the amounts paid and owed under the agreement is not in contention, then

18. Id. at 520 .

19. Id. at 520-521.

20. Unreported, 7 June 1982, Q.B. 8203-05125. (Presently under appeal).

21. (1954) 12 W.W.R. (N.S.) 445 at 450 (Man. C.A.).

22. Unreported, 19 January 1983, Q.B. 8203-18068. (Presently under appeal). 
it appears that the Court can decide the question of relief against forfeiture at the same time. ${ }^{23}$

\section{NOTICE OF DETERMINATION BY PLEADINGS}

In the previous article,${ }^{24}$ it was noted that the pleadings themselves may provide the appropriate written notice under the agreement for sale. In those cases where the agreement for sale may be terminated without notice, the pleadings will in effect provide written evidence of the decision of the vendor to determine. ${ }^{25}$ It would appear that the effective date of determination will be the date of issue of the statement of claim, ${ }^{26}$ or the date on which it was served on the purchaser. ${ }^{27}$ While the pleadings may be sufficient in cases where there is no notice of determination required, or where the notice stipulated by the contract is less than 15 days, serious problems arise where the agreement contains the 30 -day notice provision. ${ }^{28}$

These problems were highlighted in Bonnyville Rental Equipment Ltd. v. 217646 Developments $L t d .{ }^{29}$ where the agreement for sale contained a determination clause requiring 30 days notice to the purchaser. Unfortunately, the draftsman of the statement of claim in that case had wrongly assumed in his pleading that the agreement could be determined without notice.

Funduk M.C. distinguished between cases where no notice was required and where a notice period, or "period of grace", was allowed. Where there is no period of grace allowed, then a notice of determination works an immediate determination of the purchaser's interest. In such a case the commencement of proceedings will work such an immediate determination. ${ }^{30}$

However, if a certain amount of notice must be given to the purchaser, then the purchaser's interest does not determine until the expiration of this period of grace. ${ }^{31}$ The issuing of the statement of claim does not of itself work a determination. It merely commences the notice period. Master Funduk noted the difficulty of working a period of grace into a notice which is the statement of claim in circumstances where the period of grace is longer than the time the Rules of Court give to the purchaser to deliver a defence or demand of notice. ${ }^{32}$

23. See part VI, "Unconscionability", infra, and also the comments in part V. A., "Equitable Nature of Relief."

24. (1981) 19 Alta. L. Rev. 192 at 197 and the cases cited at n.40, infra.

25. MacDonald v. Paterson Park Ltd. (1983) 42 A.R. 272. (Funduk M.C.); Griffiths Motors Ltd. v. Diabol Industries Ltd., unreported, 21 January, 1983, Q.B. 8203-30124.

26. Id.; Sigma Lands Ltd. v. Felgua Investments Ltd, unreported, 21 January, 1983, Q.B. 8203-29278 (Funduk M.C.).

27. Id.; Minich v. Marthel Investments Ltd, unreported, 20 September, 1982, Q.B. 8203-19955 (Miller J.).

28. For an example of a clause requiring 30 days' notice, see (1981) 19 Alta. L. Rev. 192.

29. (1981) 39 A.R. 155 (Funduk M.C.).

30. See cases cited in n.25-27, supra.

31. March Bros. v. Banton (1911) 45 S.C.R. 338, 1 W.W.R. 544; Vladimer Holdings Co. Ltd. v. 203136 Alberta Ltd. (1982) 39 A.R. 104 (Funduk M.C.).

32. Rule 85 (1)(b). 
Citing numerous decisions requiring a vendor to comply strictly with a provision allowing him to determine the agreement for sale upon default by the purchaser, ${ }^{33}$ and in particular, requiring him to comply strictly with the requirement of giving notice contained in the agreement, Master Funduk held that the notice, being the Statement of Claim, was defective in that it failed to comply with the 30-day notice period required in the agreement. Since the Rules require that the defendant must file a defence or demand of notice within 15 days of the date of service of the statement of claim, failing to do so might result in the defendant being noted in default, thereby admitting the allegations made in the statement of claim. ${ }^{34} \mathrm{He}$ concluded:

Although a statement of claim might be an appropriate notice where no period of grace is involved, it cannot be a proper notice where there is a period of grace involved and that period of grace is longer than the time given by the Rules for entering an appearance.

\section{ELECTION/WAIVER}

In Vladimer Holdings Co. Ltd. v. 203136 Alberta Ltd. ${ }^{35}$ notice determining the agreement had been given by the vendor to the purchaser, so that at the end of the 30-day period of grace the agreement for sale had been determined and was now null and void. Funduk M.C. held that the vendor had made an election at the time of giving the notice of determination and that it was not later open to the vendor to seek any remedies (such as specific performance) which were inconsistent with the determination of the agreement for sale.

The Master adopted this approach as a result of the decision in Dunlop v. Bolster ${ }^{36}$ where the Court of Appeal had held that where the vendor is in a position to determine the agreement for sale because of the purchaser's default, and nevertheless sues for specific performance of the contract, he cannot after such election attempt to determine the agreement and resist a counterclaim by the purchaser for specific performance of the agreement.

The Master held that the facts in Vladimer were an exact reverse of the facts in Dunlop v. Bolster, and that it followed from that case that if the vendor chooses to determine the agreement extra-judicially upon default by the purchaser, then he cannot later decide after the agreement has been determined, that he now wishes to hold the purchaser to performance of the agreement and commence a specific performance action.

The Master drew further support from the line of cases, including Standard Trust Co. v. Little, ${ }^{37}$ to the effect that an election is made by the vendor when he takes out an Order Nisi from the Court. ${ }^{38}$ The notice of determination served by the vendor has the same effect as the order

33. See discussion of this point and cases cited in (1981) 19 Alta. L. Rev. 192, 195-6.

34. Rule 119, which states that silence of a pleading to allegations made in previous pleadings shall not be construed as an admission of the truth of the allegation, does not apply to a defendant in default, who is deemed to admit the plaintiff's allegations: Sulef v. Parkin (1966) 57 W.W.R. 236 at 239 (Alta. C.A.). However the admission is only as to the relief specifically claimed: Maxwell v. Cameron (1914) 7 W.W.R. 365 (Man. K.B.).

35. Supra n.31.

36. (1912) 2 W.W.R. 550; revg. 1 W.W.R. 981 (Alta S.C. en banc).

37. (1915) 8 W.W.R. 1112 (Sask S.C. en banc).

38. See (1981) 19 Alta. L. Rev. 192 at 199-200. 
obtained by the vendor in Standard Trust Co. v. Little. In effect, the parties agreed that the vendor could, upon default by the purchaser, take out an extra-judicial "Order Nisi" with the same result as in Standard Trust Co. v. Little. By serving the notice of determination, the vendor elected which remedy to take. The later commencement of an action for specific performance, by mistake or otherwise, could not change that.

Such a position, however, does not take account of statements of law, such as those by Anglin J. in Labelle v. O'Connor: ${ }^{39}$

There can be no doubt that by doing any act, after the default, which involves or implies the continued existence of the contract, the party entitled to rescind waives such right.

However, the agreement will only continue to exist if the purchaser so agrees. If he insists that the agreement has been determined, the vendor cannot change this fact by his subsequent acts.

In addition, while the position as stated in Vladimer may be acceptable in the context of the agreement being void or a nullity, there is still some difficulty in accepting the principles enunciated in Dunlop v. Bolster itself, where the initial step was to commence an action for specific performance and then to discontinue the same, followed by a purported determination of the contract. Since it has been decided in a number of cases that inconsistent remedies or forms or relief may be properly pleaded in the parties' pleadings as alternatives, ${ }^{40}$ and that the time of election in specific performance actions is the date on which the Order Nisi is obtained,"1 it is difficult to see why the vendor who has not yet made his election in terms of the authorities, cannot be allowed to change his mind, notwithstanding the decisions in Dunlop v. Bolster and Vladimer. There is no doubt that the concepts of election and waiver overlap in this regard and this matter has not been clearly resolved by the courts to date.

\section{TIME OF THE ESSENCE OF THE AGREEMENT}

\section{A. WHERE NOT SPECIFICALLY STATED IN AGREEMENT}

Certain stationers' forms, in common use in Alberta, for some reason do not contain the express provision found in other forms of agreement for sale that time is of the essence of the agreement. In a number of cases, however, the courts have considered that time is of the essence of the contract even if it has not been expressly so made by the terms of the agreement. ${ }^{42}$ This has been done particularly where the property is speculative in nature and is not being occupied by the parties. ${ }^{43}$ In Forfar v.

39. (1908) 15 O.L.R. 519, 547 (Div. Ct.). See also Crawley v. Hamley (1909) 11 W.L.R. 574 (Man. K.B.); Timmins v. Smith (1910) 14 W.L.R. 503 (Sask. S.C.).

40. Pitt River Lumber Co. v. Shaake (1914)6 W.W.R. 994 (B.C.S.C.); Standard Trust Co. v. Little (1915)8 W.W.R. 1112 at 1116 (Sask. S.C. en banc); Elliott v. Barry [1920]2 W.W.R. 478 (Alta. A.D.); Hole v. Wilson (1911) 16 W.L.R. 352 (Sask S.C. en banc); Lee v. Sheer (1914) 7 W.W.R. 927 (Alta A.D.); Regina Brokerage and Inv. Co. v. Waddell (1916) 10 W.W.R. 364 (Sask S.C. en banc); Dobson v. Winton \& Robbins Ltd. [1959] S.C.R. 775 at 779. Scott Bros. Gravel Co. Ltd. v. N.W. Hullah Corporation Ltd. (1967) 59 W.W.R. 173 (B.C.C.A.).

41. See discussion and cases cited in (1981) 19 Alta. L. Rev. 192 at 199.200.

42. O'Kelly v. Downie (1914) 17 D.L.R. 395 (Man. C.A.).

43. Doyle v. Low (1932) 41 O.W.N. 28(C.A.); Harris v. Robinson (1892) 21 S.C.R. 390 at 404; O'Gorman v. Fitzmaurice (1911) 19 O.W.R. 876, 2 O.W.N. 1480 (H.C.); Sanderson v. Burdett (1869) 16 Gr. 119 at 122 (Ch. Ct.); McCready v. Clark (1910) 14 W.L.R. 480 at 485-6 (B.C.S.C.), where there was neither an expressed stipulation that time should be of the essence, nor any provision for cancellation and resale upon non-payment. 
Sage, ${ }^{44}$ McGuire J. held that by the wording of the Agreement for Sale time was of its essence, although there was no specific stipulation to that effect.

These authorities were followed by Purvis J. in Tymo v. Wild Rose Properties Ltd. ${ }^{45}$ where his Lordship noted that the purchasers had acknowledged purchasing the land for speculation. His Lordship accordingly held that time was of the essence in connection with the agreement for sale, even though such wording was not found in the agreement itself. His Lordship also referred to the case Doyle v. Low ${ }^{46}$ where the reason for the purchaser's default was that the land had been bought for speculation and the economic depression had made the speculation a failure. Under these circumstances, it had been held that the contract had been abandoned, and the vendor's right to cancellation was absolute.

\section{B. TIME OF THE ESSENCE - EXTENSION OR WAIVER OF DEADLINE}

The effect of the inclusion (or failure to include) a clause in the Agreement to the effect that time is of the essence of the Agreement, the effect of the extension or waiver of the deadline and the setting of a new deadline have caused probably the most disagreement in this area of the law in the recent written decisions of the Alberta Courts. Two cases in particular are irreconcilable in their approach and reasoning, and yet in neither case can the decision be said to be without support from judicial authority.

In Landbank Minerals Ltd. v. Wesgeo Enterprises Ltd.,$^{47}$ Hetherington $J$. had before her an agreement for sale of certain petroleum and natural gas interests. The agreement provided that time should be of the essence. However, the parties agreed to a postponement of the closing "until Friday, August 17, 1979 at 10:00 a.m. or a later mutually agreeable date". On August 17, 1979, the parties met to close the deal but the vendors were unable to provide the necessary evidence of delay rental payments. The purchaser terminated the Agreement and demanded the deposit back. The vendor refused and on August 20, delivered evidence of the delay rental payments. Hetherington J. held ${ }^{18}$ that in the circumstances it was neither unjust nor inequitable to give effect to the provision making time of the essence.

Her Ladyship followed the judgment of Lord Cranworth V.C. in Parkin v. Thorold ${ }^{49}$ and the decisions in Barclay v. Messenger, ${ }^{50}$ Bogue Electric of Canada Ltd. v. Crothers Manufacturing Ltd. ${ }^{51}$ and Tropical Traders Ltd. v. Goonan. ${ }^{52}$ She held that, in the absence of circumstances making it unjust or inequitable for a party to insist that time is of the essence, an extension of time for performance to a specified date simply results in the substitution of a later date for the one stipulated in the agreement, and

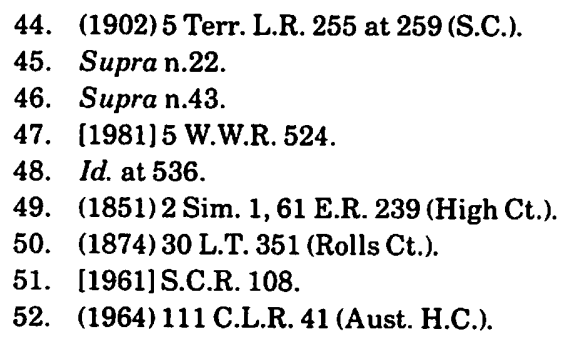


that time remains of the essence.$^{53}$ In so deciding, her Ladyship refused to follow the decisions in Kilmer v. B.C. Orchard Lands Ltd. ${ }^{54}$ Hanson v. Cameron ${ }^{55}$ Whittal v. Kour, ${ }^{56}$ and Adjala Properties Ltd. v. Town of Sundre ${ }^{57}$ acknowledging the two conflicting lines of cases in Canada.

However, in World Land Ltd. v. Daon Development Corporation, ${ }^{58}$ it was this second line of authority that was preferred and followed by D.C. McDonald J. In that case, World Land bought land from the defendants (vendors) by way of an agreement for sale for the purpose of a commercial development. The agreement provided that construction must be commenced by October 31,1979 , and that time should be of the essence. In August of 1979, the purchaser asked for an extension which the vendors gave by letter, stating, inter alia: ${ }^{59}$

We will . . . agree to an extension of the original commencement date from 365 days to 427 days from the October 13, 1978 adjustment date. This will give you until December 31,1979 to meet this requirement.

This extension however, is conditional upon your compliance [with certain specified payments].

Save and except for the extension and its conditions as outlined above, all other terms and conditions detailed in our land purchase agreement dated October 30, 1978 remain unchanged.

Construction was not commenced by December 31, 1979, and the vendors served the purchaser with a notice to take proceedings on its caveat. The purchaser sued for specific performance, while the vendors counterclaimed for possession, discharge of the Caveat, and a declaration that they were entitled to retain the money already paid as liquidated damages. D.C. McDonald J. dismissed both actions, stating that the correct remedy was for the vendors to determine the agreement and then to have the court declare that they had done so validly. ${ }^{60}$

In considering whether the purchasers were entitled to specific performance, his Lordship had to decide whether time was still of the essence between the parties on December 31,1979. He found that the letter quoted above made no mention of whether time would still be of the essence and held that accordingly, time was no longer of the essence. His Lordship referred to the conclusions of Hetherington J. in the Landbank Minerals case $^{61}$ and the authorities on which she relied, but was of the opinion that her Ladyship's decision was not the law of Canada ${ }^{62}$ Rather, the law is that "an extension of time with respect to a particular instalment destroys the essentiality of time with respect to that instalment at least". His Lordship also cited with approval Steedman v. Drinkle ${ }^{63}$ and the Hanson, Wittal, and Adjala cases referred to by Hetherington J., ${ }^{64}$ and refused to treat the conclusions reached in those cases as having been swept away by the

53. Supra n.47 at 535.

54. [1913] A.C. 319, 3 W.W.R. 1119 (P.C.).

55. [1949] S.C.R. 101, 1 D.L.R. 16.

56. (1969) 71 W.W.R. 733, 8 D.L.R. (3d) 163 (B.C. C.A.).

57. (1981) 28 A.R. 379 (C.A.).

58. [1982] 4 W.W.R. 577 .

59. Id. at 585 .

60. Id at 601.

61. Supra n.47.

62. Supra $\mathrm{n} .58$ at 593 .

63. [1916] A.C. 275, 9 W.W.R. 1146 (P.C.).

64. Supra, notes 55-57. 
decision of the Supreme Court of Canada in the Bogue Electric case. ${ }^{65}$

This conflict in the authorities is most unsatisfactory, particularly in light of the refusal of the Courts of Equity to order specific performance (i.e. to relieve against forfeiture of the purchaser's interest in the land) as distinct from the Court's ability to relieve against forfeiture of the money paid, in cases where time is stated to be of the essence ${ }^{66}$ Even if the Court is prepared to consider relief from forfeiture of the land in a particular case, ${ }^{67}$

... the decision as to whether time was the essence [is] a matter of potential importance because a decision that time was of the essence may bar or reduce the possibility of the purchaser obtaining specific performance or some other equitable relief.

The logic of the approach taken by Hetherington J. in Landbank Miner$a l s^{68}$ and the Supreme Court of Canada in Bogue Electric ${ }^{69}$ can perhaps best be explained by the statements of Jessel, M.R. in Barclay v. Messenger: ${ }^{p 0}$

If a man says a contract is to depend upon a payment of money by a certain day, and the party entitled to receive the money says I will extend your time, I will give you a week or a month, why that should put the party in a better position than if it had been originally put in the contract, I cannot conceive. It appears to me plain that a mere extension of time, and nothing more, is only a waiver to the extent of substituting the extended time for the original time, and not an utter destruction of the essential character of the time.

Despite the uncertainty with respect to the application of the principles in Barclay v. Messenger in Canada ${ }^{71}$ it is submitted with great respect that the approach advocated in World Land, Whittal, and Hanson, namely that an extension destroys the essentiality of time, is too extreme and involves an unwarranted interference by the Courts in the ability of the parties to make their own contractual agreements and amendments thereto.

\section{NOTICE MAKING TIME OF THE ESSENCE}

\section{Maintaining essentiality of time in agreement}

Even if the courts are not, for the present at least, prepared to adopt the approach of Hetherington J., it is submitted that an extension can be granted maintaining time of the essence, where it is expressly stated that time shall be (or continue to be) of the essence of the extension. In Woels $\mathrm{v}$. Mashinter, ${ }^{72}$ Steer J. stated:

It is established, however, (Hanson v. Cameron [1949] S.C.R. 101 at 104, [1949] 1 D.L.R. 16; Allarco Developments Ltd. v. Moran [1971]2 W.W.R. 605 (Man.)) that merely making a new day for performance is not sufficient to make time again of the essence, even if that new day is a

65. Supra, n.51.

66. Steedman v. Drinkle, supra n.63; Brickles v. Snell [1917] 1 W.W.R. 1059 (P.C.). See further (1981) 19 Alta L. Rev. 192 at $200 \mathrm{ff}$. .

67. World Land Ltd. v. Daon Development Corp. Ltd, supra n.58 at 594.

68. Supra n.47.

69. Supra n.51.

70. Supra n.50 at 354. See also the reasons of Kitto J. in the High Court of Australia in Tropical Traders Ltd. v. Goonan (1964) 111 C.L.R. 41 at 53, quoted by Hetherington J. in Landbank Minerals Ltd. v. Wesgeo Enterprises Ltd. [1981] 5 W.W.R. 524 at 532.

71. Hanson v. Cameron [1949] S.C.R. 101, 1 D.L.R. 16; Whittal v. Kour (1969) 71 W.W.R. 733, 8 D.L.R. (3d) 163 (B.C.C.A.); and World Land Ltd. v. Daon Development Corp. Ltd. [1982] 4 W.W.R. 577 all reject the principles in Barclay v. Messenger. See also the discussion by Stratton J. in Kapchinsky v. Begam Holdings Ltd. (1982) 20 Alta. L.R. (2d) 294 at 303.

72. [1976]5 W.W.R. 79 at 87 (Alta. S.C.). 
reasonable time in advance. The notice must in some way bring home to the defaulting party that time is again of the essence or being made of the essence. It is not, as I apprehend the situation, necessary to use express words stipulating time to be of the essence. It is sufficient, in my opinion, to bring home to the defaulting party that if the new day is not met the party serving the notice will treat the contract at an end. This conclusion is established by the passages just quoted from Stickney v. Keeble [1915] A.C. 386, and such an intimation was held sufficient in Dobbin v. Niebergall (1920) 48 O.L.R. 343 at 345 and 346, 56 D.L.R. 510.

...

It is my opinion that it is not necessary to expressly state that time shall be of the essence in the notice provided it is clearly brought home that the contract will be treated at an end and the time given in which to perform is a reasonable time.

This reasoning was followed and adopted by Stratton J. in Kapchinsky v. Begam Holdings Ltd. ${ }^{73}$ who agreed that the party being given the new deadline should be left in no doubt that time with respect to the newly established date is of the essence. In Adjala Properties Ltd. v. Town of Sundre, ${ }^{74}$ the Court of Appeal dealt with an agreement to sell land by the town to the Plaintiff for development. Although the original agreement had provided that time was to be of the essence, the town had agreed to extend the deadline from May 13th to May 31st, 1976. McDermid J.A., for the Court, stated: ${ }^{75}$

It was not specified in the extension that time was to continue to be of the essence. Such being the case, I am of the opinion that it was no longer of the essence unless and until the town gave notice to the company that such was the case. [Emphasis added]

In light of these decisions, what must the vendor do when he wishes to extend the deadline for payment, construction or some other requirement of the contract, and yet not lose his ability to stand by the terms of his contract in the event of failure to comply with the extended deadline?

It would seem that, until a reconsideration of the principles of Barclay v. Messenger, ${ }^{76}$ the setting of a new date without more will not maintain the essentiality of the new deadline. ${ }^{77}$ Even where the deadline is extended by a specific number of days, and the new date is clearly communicated, this may not be sufficient. ${ }^{78}$

A demand or trust condition that the conveyancing documents be returned if payment or other requirement is not satisfied on or before the new deadline is not enough.$^{79}$ Confirmation that on the new date all terms of the agreement (which include a provision that time is of the essence) will remain unchanged, except for the extended date, also appears to be insufficient. ${ }^{80}$ The notice of extension should either state that time will be or continue to be of the essence of the new deadline, or alternatively, that upon failure to meet the date, the agreement will be at an end. ${ }^{81}$

\section{Imposing an essential deadline}

73. (1982) 20 Alta. L.R. (2d) 294 (Q.B.).

74. (1981) 28 A.R. 379 (C.A.).

75. Id. at 384 .

76. (1874) 30 L.T. 351 (Rolls Ct.).

77. Woels, supra n.72; Kapchinsky, supra n.73; Adjala Properties, supra n.74.

78. World Land, supra n.71; contra: Landbank Minerals, supra n.70.

79. Woels, supra n.72.

80. World Land, supra n.71.

81. Woels, supra n.72, Kapchinsky, supra n.73. 
Even in circumstances where time is not of the essence of the agreement itself, it is possible to make a time of the essence in an agreement as can be seen from the following authorities. In Woels v. Mashinter ${ }^{82}$ Steer J. was faced with a situation where the vendor had initially stipulated that time should be of the essence. His Lordship stated: ${ }^{83}$

Since, as I have said, the defence is that this payment was not made on time and that time was the essence of the agreement, it is necessary to define the law with respect to the position of parties to an agreement for the sale of land where there is a provision that time be of the essence and it has been waived and what must be done by the vendor in order to put himself into a position to resist an action for specific performance thereafter.

\title{
He continued:84
}

The jurisdiction of the Court in cases of this kind is more fully explained in Stickney v. Keeble [1915] A.C. 386. In this case the House of Lords explained what a vendor or purchaser may do, having waived the clause, or in a case where there is no such clause, and time is not of the essence due to other circumstances, to put himself again in a position in which he can bring the contract to an end for failure of the other party to perform on time. The pertinent passages on this point are at p. 413:

'After the long delay which had taken place the plaintiff had a right to make time of the essence of his contract by serving the defendants with a notice sufficient in point of time to enable them to complete his title, and he could only be deprived of this right by contract or by conduct of his own which would make it unfair for him to insist upon his right.'

However, as already noted, his Lordship was of the opinion that merely making a new date for performance is not sufficient to make time again of the essence, even if the new day is a reasonable time in advance. ${ }^{85}$

In Ajit v. Sammy ${ }^{86}$ the contract did not make time of the essence. In that case the closing date should have been at the expiration of the three months covered by the necessary advertisement of the sale. The agreement was dated 31 July, 1958, and it appears from the correspondence that the advertising concluded on 8 November, 1958. On 3 February, 1959, a letter was written on behalf of the vendor to the purchaser, including the following statement:

We are therefore instructed to inform you that time is of the essence of the contract and that unless you attend Transport Court on Monday next, the 9 th instant at 2:00 p.m., accept trans. port, pass the mortgage and pay the balance of purchase price, viz. 4,000 Dollars, our client will have no alternative but to cancel the sale and forfeit the deposit and furthermore, will hold you responsible for any loss or damages that he may incur in this matter.

The Privy Council had to decide whether the very short notice of six days was reasonable in the circumstances. Their Lordships held the agreement cancelled, citing and following the decision in Stickney v. Keeble: ${ }^{87}$

Where in a contract for sale of land the time fixed for completion is not made of the essence of the contract, but the vendor has been guilty of unnecessary delay, the purchaser may serve upon the vendor a notice limiting a time at the expiration of which he will treat the contract as at an end, and in determining the reasonableness of the time so limited the court will consider not merely what remains to be done at the date of the notice, but all the circumstances of the case, including the previous delay of the vendor and the attitude of the purchaser in relation thereto.

In Forfar v. Sage, ${ }^{88}$ an agreement for sale had been executed stipulating

\author{
82. Supra n.72. \\ 83. Id. at 84 . \\ 84. Id. at 86 . \\ 85. Id. at 87 . \\ 86. [1967] I A.C. 255, [1966] 3 W.L.R. 983 (P.C.). \\ 87. [1915] A.C. 386 (H.L.). \\ 88. (1902) 5 Terr L.R. 255 (S.C.).
}


certain payments to be made on certain dates, in default of which the agreement should become immediately void and any money paid forfeited to the vendor. Partial payment was received under the agreement, and some of these payments were accepted although late and of insufficient amounts. McGuire J. stated: ${ }^{89}$

Then came the notice of March 2, 1901, which, while without prejudice to existing rights, fixed April 5, 1901 as the date when the contract must be completed, and the wording of that notice is very peremptory and distinct that on default the Agreement would then be void. Default was made and it seems to me that [the vendor] was justified in treating this default as an abandon. ment by the purchasers of the contract. Bowen L.J. in Howe v. Smith (1884) 27 Ch. D. 89, said: 'though the purchaser may appear to be insisting on his contract, in reality he has so conducted himself under it to have refused, and given the other side the right to say he has refused, performance.

...

But whatever inferences may be drawn as to an intention not to insist on this default in payment of the third instalment, what evidence is there of waiver of the default in complying with the notice of March 2, 1901?

McGuire J. held that there was no subsequent waiver of the default in complying with the notice given. His Lordship reviewed the cases where notice had been given and concluded: ${ }^{90}$

From the foregoing cases it seems to me that, having given notice limiting a reasonable time within which to complete, and that in default, the agreement would be treated as at an end, [the vendor] was not bound to give any further notice after default . . . and that mere delay to enforce his right to possession in the absence of any negotiations or other conduct showing that he did not treat the agreement as abandoned, was not a waiver. As said in Benson v. Lamb [(1846) 9 Beav. 50250 E.R. 438, 440], 'the time having expired, the contract was at an end.' If it is at an end, the purchasers are not entitled to specific performance.

\section{REASONABLENESS OF THE TIME STIPULATED IN THE NOTICE}

Some examples of the reasonableness of the time have already been provided. $^{91}$ In Charles Rickards v. Oppenheim ${ }^{92}$, Denning L.J. reviewed the considerations that the Court must make in establishing whether notice was reasonable:

In this case, not only did the Defendant press continually for delivery, not only was he given promises of speedy delivery, but on the very day before he gave the notice, he was told by the subcontractors' manager who was in charge of the work, that it would be ready with in two weeks. He then gave a four weeks' notice. The judge found that it was reasonable notice and in my judgment, there is no ground on which this court could in any way differ from that finding. The reasonableness of the notice must, of course be judged at the time at which it is given. It cannot be held to be a bad notice because, after it is given, the suppliers find themselves in an unanticipated difficulty in making delivery.

In Shortt v. Liebelt ${ }^{93}$ the time of closing was extended a number of times, until finally a notice was given on June 1, 1954:

... that time is of the essence and require that the sale be completed on or before the 14 th day of June, next. In the event that the sale be not completed on or before the 14 th day of June next, the agreement to sell is at an end.

\section{Moorehouse J. reviewed the facts and quoted from Stickney v. Keeble $:^{94}$}

When I am asked to say that this time was insufficient I must see what had to be done within the time.

89. Id. at 259 .

90. Id. at 262.

91. Ajit, supra n.86 - 6 days; Stickney, supra n.87 - 14 days; Forfar, supra n.88 - 34 days.

92. [1950] 1 A11 E.R. 420 at 424 (C.A.), referring to Stickney v. Keeble, supra n.87.

93. [1955] O.W.N. 491; affd. at 690. (C.A.).

94. Supra, n.87 at 397, per Earl Loreburn. 
Moorehouse J. concluded that the fourteen days notice gave sufficient time to conclude all the matters of conveyancing, and this conclusion was confirmed by the Court of Appeal.

In Wickson v. Pearson, ${ }^{95}$ the original agreement for sale of the land included a provision that time was of the essence of the contract. However, Wallbridge C.J. noted: ${ }^{96}$

The Plaintiff, however, did not rely upon that solely, but strives to make time the essence of the contract by the notice of the 6th of November, 1885 (served 7 th November).

It is now well settled that time can be so made of the essence of the contract by notice distinctly and unequivocally expressed.

In that case, the notice, served on 7 November, 1885, required payment of the money due on the contract on or before the 27 November, 1885 . Payment was not made by that date for no reason other than certain fears by the purchaser which the Court held to be unjustified. The purchaser did, in fact, tender the money on 3 December to the Plaintiff. Wallbridge C.J. reviewed whether the time from 7 November to 27 November was a reasonable time within the meaning of that expression as used in legal phrasology: $:^{97}$

Was the time reasonable? This must be determined from the circumstances actually existing. There was nothing required of the defendant Mrs. C. but to pay the money: no question of time to investigate title is claimed; no other objection is offered excepting the plaintiff's supposed disqualification as prowling assignee; and the defendant's fear that whilst her case against Pearson and others was standing for judgment she might by payment be said to have affirmed the contract. In my opinion neither of these forms an excuse. In Benson v. Lamb, 9 Beav. 502, time may be made essential. The parties here were clearly at arm's length and hostile. Why didn't she redeem? She chose to allow the time to pass, and, in my opinion, she cannot recall it.

\section{EQUITABLE JURISDICTION TO RELIEVE AGAINST FORFEITURE OF MONEY PAID}

\section{A. EQUITABLE NATURE OF RELIEF}

\section{An agreement for sale commonly in use provides in part:}

... and the purchaser shall have no right to reclaim any monies paid in respect of this agreement, and the same may be retained by the vendor as liquidated damages.

It is clear that at law, the parties to the contract will be held to the precise terms of their agreement..$^{98}$ However, courts of equity look at the substance of the transaction as distinguished from the letter of the agreement. ${ }^{99}$

To escape from the legal consequences of his default under the agreement, (which include the forfeiture of the money paid), the purchaser must be able to invoke the equitable jurisdiction of the court. What must the purchaser show in order to obtain equity's assistance? In the most common circumstance, where the purchaser has failed to make the payment due, must the purchaser show that he is ready, willing and able to make the required payment before he can approach a court of equity for its assistance?

95. (1886) 3 Man. R. 457 (Q.B.).

96. Id. at 459 .

97. Id. at 461 .

98. Parkin v. Thorold (1852) 22 L.J. Ch. 170 at 172, 51 E.R. 698, per Romilly M.R.; Centurian Ridge Farms Ltd. v. Boyle (1978) 7 Alta. L.R. (2d) 340 at 348, per Miller J.; affd. C.A. 11 March, 1980.

99. Id.; Drinkle v. Steedman [1916] 1 A.C. 275 at 279,9 W.W.R. 1146 at 1148 (P.C.). 


\section{In Moore \& MacDowall v. Stewart, it was held: ${ }^{100}$}

So far as a purchaser is concerned, a valid cancellation notice puts an end to the contract. Having agreed that the vendor might do this and retain the moneys paid, the purchaser is bound by his contract. To escape from the consequences of his agreement he must satisfy a Court of Equity that he should be relieved from the forfeiture caused by his default. This he may do by promptly tendering the purchase money on receiving notice of the cancellation, thus remedying his default, and, if this be not accepted, promptly coming to the court for relief. If he is not prepared to remedy his default he must abide by the consequences thereof.

\section{In Hole v. Wilson, Lamont J. stated: ${ }^{101}$}

But from the fact that the Court has jurisdiction to relieve, it by no means follows that the Court should relieve. Before a party appealing to the equitable jurisdiction of the Court is entitled to relief, he must make out a proper case for the exercise of that equitable jurisdiction to which he appeals. Has the defendant here made out such a case? I am very clearly of opinion that he has not. It is a principle of equity that he who seeks equity must do equity. Has the defendant done equity? He signed a contract that by which he agreed to pay $\$ 2,000$ on the 4 th December, 1907 , and he agreed that, if he did not pay it on that date, the plaintiff could declare the contract null and void, and he was to have no claim for the return of the purchase-money paid. He did not make the payment; he was repeatedly requested to pay, and either refused or neglected so to do. In order to do equity to the plaintiff he must offer her all the advantages she would have received from the performance of the contract, that is, the purchase-money and interest due thereunder, and when he comes to this Court claiming equity for himself, he must satisfy the Court that he was prepared and is still prepared to hand over to the plaintiff the purchase-money and interest due her under the contract and all other advantages which the performance of the contract would give her. This is a condition precedent to the granting of equitable relief to a purchaser against forfeiture resulting from his own agreement and default. If the defendant cannot show this, he is not in a position to say that he has done equity, and that, so far as possible, he has remedied the default that occasioned the forfeiture. I agree with the language used by Prendergast, J., in the Court below, where he said: "In order to have a standing before this Court, the defendant must at least be in a position to say: 'I am ready to perform my part of the agreement; I ask the Court to compel the plaintiff to perform hers; and if she does not, I claim a return of the $\$ 2,000$.' "

Here the defendant is not now ready and willing, nor has he ever been ready and willing, to pay the instalments of the purchase-money. He does not ask that the plaintiff be compelled to carry out the contract, because he is not in a position to perform his part of it if she were willing. In these circumstances, he has not done equity to the plaintiff, and is, therefore, not in a position to ask a Court of equity to consider the merits of his case.

If he had, after notice by the plaintiff declaring the contract null and void, offered her the purchase-money and any other advantage reserved to her by the contract, and she refused to accept, he would then have been in a position to ask the Court for relief, and in that case the Court would have to consider whether the facts and circumstances of the case were such as to entitle him to relief. But until he does that, the Court, in my opinion, is not called upon to consider whether the forfeiture is inequitable or otherwise or in any way deal with the case on its merits. [Emphasis added]

\section{In Zimmer v. Karst, the same judge stated: ${ }^{102}$}

The purchaser cannot come to a Court of equity relying on his own default. He must first purge himself of that default, and that he can only do by coming to that Court ready and willing to perform all that he agreed to do in the contract. This, it seems to me, is a condition precedent to his claim being heard by the Court. The ground upon which he must necessarily stand, when asking the Court to relieve him against the consequences of his own default, is that he has remedied that default in so far as it is possible to remedy it. In this case, the plaintiff not only has failed to pay the balance of the purchase-money, but he expressly admits that he has never tendered or offered to pay the same. He simply refused to pay the purchase-money until the defendant was forced to determine the contract, and now he says, 'Give me my money back.' To return it to him, in these circumstances, would be to violate that principle of equity and justice upon which the Court should act.

Reference is also made to similar comments by the Saskatchewan Supreme Court en banc in Cowie v. McDonald. ${ }^{103}$

100. (1914) 7 W.W.R. 991 at 993 (Sask. S.C.).

101. (1911) 16 W.L.R. 352 at 355 (Sask. S.C. en banc).

102. (1910) 15 W.L.R. 58 at 65.6 (Sask. S.C.).

103. [1917] 2 W.W.R. 356 at 360 . 


\section{In Forfar v. Sage, McGuire J., held: ${ }^{104}$}

The purchasers have not shown themselves ready to carry out the agreement; not even now are they or the receiver (as he admits) able to pay. As said by Lord Justice Cotton in Howe v. Smith, specific performance is given only "to those who are ready and prompt". It was said in that case: "He was not ready with the money in order to purchase the estate, and at the time when the action was commenced if the vendor had said 'Where is your money? Produce it, and I will make the conveyance', he would not have been able to produce the money." The same state of facts exist here.

This approach was more recently reflected in the opinion of Romer L.J. in Stockloser v. Johnson: ${ }^{105}$

There is . . nothing inequitable per se in a vendor, whose conduct is not open to criticism in other respects, insisting upon his contractual right to retain instalments of purchase-money already paid.

His Lordship further stated: ${ }^{106}$

... It seems to me that in the long run it is much better that people who freely negotiate and conclude a contract of sale should be held to their "bargain" rather than that the judges should intervene by substituting, each according to his own individual sense of fairness, terms which are contrary to those which the parties have agreed upon for theinselves.

A similar approach has been taken by the Supreme Court of Canada in cases such as Dimensional Investments Ltd. v. The Queen ${ }^{107}$ and Canada Egg Products Ltd. v. Canadian Doughnut Co. Ltd. ${ }^{108}$ Even in March Bros. $\&$ Wells v. Banton, ${ }^{109}$ Davies J., with whom the majority of the Supreme Court of Canada agreed, stated:

I take it as clear that in all cases the question of the right of the purchaser to the return of monies paid by him, whether by way of deposit only or "by way of deposit and as part payment of the purchase" or as part payment of the purchase money only is a question of the conditions of the contract, and the intentinn of the parties as expressed in or to be implied from those conditions.

This statement was referred to by Funduk M.C. in MacDonald v. Paterson Park Ltd. ${ }^{110}$ where the Master found that in that case the conditions of the agreement and the intention of the parties were clear - the vendors were to retain the purchase money paid if the agreement was determined.

However, in a number of cases, the courts have adopted a more generous approach to the question of relief from forfeiture of the money paid. This approach is perhaps most clearly summed up by Denning L.J. in Stockloser v. Johnson:"1"

... [I]n the proper case, there is an equity of restitution which a party in default does not lose simiply because he is not able and willing to perform the contract. Nay, that is the very reason why he needs the equity. The equity operates not because of the Plaintiff's default, but because it is in the particular case unconscionable for the seller to retain the money. In short, he ought not to unjustly enrich himself at the Plaintiff's expense. This equity of restitution is to be tested I think, not at the time of the contract, but by the conditions existing when it is invoked.

104. Supra n.88 at 262.

105. [1954] 1 Q.B. 476, 1 A11 E.R. 630, 2 W.L.R. 439 at 458 (C.A.).

106. Id., 2 W.L.R. at 459.

107. (1967)64 D.L.R. (2d) 632 at 638. The comments of D.C. McDonald J. in World Land Ltd. v. Daon Development Corp. Ltd. [1982] 4 W.W.R. 577 at 608 should be noted, where his Lordship states his opinion that "no heed should be given to the views expressed by Romer L.J. in Stockloser v. Johnson and Ritchie J. in Dimensional Invts. Ltd. v. R. ..."

108. [1955]S.C.R. 398 at 410.

109. (1911) 45 S.C.R. 338 at 340, 1 W.W.R. 544, referred to at trial by Belzil J. in City of Edmonton v. A \& M Developments Ltd. (1980) 17 R.P.R. 304 at 312; (1981)C.A. \#13938; leave to appeal refused (1981) 32 A.R. 175 (S.C.C.).

110. Supra n.25.

111. Supra n.105 at 450 (W.L.R.). See also similar comments of Denning L.J. at [1954] 2 W.L.R. 448. 
It should be noted that this type of approach is somewhat difficult to rationalize with earlier comments of Denning L.J., ${ }^{112}$ where his Lordship made a distinction between cases where the vendor is attempting to exact a penalty or payment of an extravagant sum, and cases where the vendor only wanted to keep the money which already belonged to him, having been handed to him in part payment of the purchase price, and which, as soon as it was paid, belonged to him absolutely.

In Coronado Developments Ltd. v. W.E.D. Developments Ltd. ${ }^{113}$ Cawsey $J$. quoted the above passage from the judgment of Denning L.J., but in that case went on to find that there was nothing unconscionable in the vendor retaining the money already paid under the agreement for sale. In Tymo v. Wild Rose Properties Ltd., ${ }^{114}$ Purvis J. distinguished between specific performance of the agreement (where the purchaser does have to show his willingness and ability to bring the agreement into good standing) and relief from forfeiture of the money paid:

... in the latter situation, it makes little sense to require the purchaser in default to pay more money before the court would consider ordering some or all of the purchase price to be returned to him. This absurdity was commented on by Lord Denning in Stockloser v. Johnson.

It is my conclusion that the purchaser in default under an agreement for sale need not tender the funds necessary to bring the contract into good standing as a precondition in all cases before he can apply to the courts for equitable relief from forfeiture of payments already made.

However, is this proposition so "absurd", especially in Alberta where section 39 of the Law of Property Act ${ }^{115}$ grants statutory relief from forfeiture in appropriate cases, not as a matter of judicial discretion, but as a mandatory form of relief which the courts must grant? If the purchaser in default "pays more money", it will not be a question of a return of the money paid - rather the agreement will be reinstated as if there had been no default. If the purchaser fails to "pay more money", he cannot seek relief under section $39 .{ }^{116}$ Why should he be entitled to relief under the equitable jurisdiction of the court, which is certainly narrower in scope than section 39? Why should the same principles as the courts of equity apply to a purchaser's claim to specific performance (i.e. relief from forfeiture of the interest in the land) not apply to the purchaser's claim to return of the money?

\section{B. "WILLING, READY AND ABLE"}

Even where time is not of the essence, equity requires that a purchaser who seeks relief from forfeiture show that he has at all times been ready, willing and able to complete his part of the contract. Two recent cases have dealt with the question of whether a party is "ready, willing and able to complete his part of the contract". In William Anthony Holdings Ltd. v. Belevetz, ${ }^{117}$ Wilson J. was dealing with a contract in which time was made of the essence. He indicated that: ${ }^{118}$

Before a party to a contract in which time is made of the essence can secure specific performance,

112. Id. at 447 .

113. (1982) 24 A.L.R. (2d) 34, 42 A.R. 283 (Alta. Q.B.).

114. Supra n.22.

115. R.S.A. 1980 , c. L-8.

116. Coronado Developments Ltd. v. W.E.D. Developments Ltd, supra n.113.

117. [1977] 4 W.W.R. 135 (Man. Q.B.).

118. Id. at 143 . 
he must show that he is ready, willing and able to carry out the agreement and that he has not been the cause of the other party's delay or default.

The significance of tender is as proof that the party tendering is ready, willing and able to complete his part of the contract.

His Lordship cited from Bayshore Investments Ltd. v. Wilson: ${ }^{119}$

It cannot be said that a party is ready, willing and able to complete if he simply demonstrates that he may consider becoming ready if tender is made upon him.

The decision in William Anthony Holdings Ltd. v. Belevetz was followed in Centurian Ridge Farms Ltd. v. Boyle, where Miller J. stated: ${ }^{120}$

In summary, it is my view that the law in the Province of Alberta relating to this point is the same as that expressed by the courts in Manitoba and Saskatchewan, namely, that the onus is upon the purchaser to make a tender of the funds required to close on or before a stipulated closing date in order to establish that he is ready, willing and able to complete the transaction, and this, in the absence of agreement to the contrary, must be done if the purchaser does not wish to lose his rights under the contract irrespective of whether the vendor proffers in trust the conveyances which will ultimately be required to conclude the sale. [Emphasis added]

In that case, the deadline for payment was October 27th and his Lordship held that "nothing even approaching a tender was made until November 19 th, and by then the vendor had clearly annulled the transaction". ${ }^{121}$

In Schmitt v. Terrace Corporation (Construction) Ltd. ${ }^{122}$ Bracco J. held that the purchaser had tendered the necessary funds (they were refused) so that he was "ready, willing and able to conclude the transaction at all material times." Reference is also made to Archdekin v. McDonald, where MacDonald J. Held:123

To constitute a valid tender of money, there must, in the absence of some act or condition which amounts to a waiver, be something more than a mere readiness and willingness to pay, even though expressed; there must be an actual production of the money.

\section{SUMMARY}

With respect, the approach taken by the Courts to relief from forfeiture of land on the one hand and money paid on the other does not reflect a consistent approach to interpretation of the two parts of the one clause in the agreement for sale in which both of these vendor's remedies are found. To treat the vendor's ability to retain the land in a different fashion to his ability to retain the money, amounts not just to judicial interference with an agreement made by the parties, ${ }^{124}$ but to selective judicial interference on the stated basis that the retaining of the money is in fact a penalty against which equity will relieve.

However, in adopting this approach, one is in fact putting the cart before the horse. It is submitted that before a purchaser can obtain even a hearing in equity (as to the question of penalty, relief from forfeiture, etc.) he must $d o$ equity, namely tender to show that he is ready, willing and able to remedy his default. A review of many of the cases in this area indicate that, in most instances where relief was granted, a tender had been made

119. (1975) 11 O.R. (2d) 392 (H.C.).

120. (1978) 7 Alta. L.R. (2d) 340 at 350.1; affd. C.A. 11 March, 1980.

121. Id. at 351 .

122. (1981) 30 A.R. 518, 526.

123. (1912) 1 W.W.R. 1014 at 1016.

124. See Gray v. Abbott [1923]2 W.W.R. 424 at 427 (Man. C.A.). 
and often an action for specific performance had also been brought. ${ }^{125} \mathrm{On}$ the other hand, in cases where no relief against forfeiture of the money was granted, it has appeared that no tender was ever made. ${ }^{126}$

VI. UNCONSCIONABILITY

\section{A. BURDEN OF PROOF}

As was seen in the previous article,${ }^{127}$ some confusion had arisen as a result of the apparent conflict between the opinion of Belzil J. in City of Edmonton v. A \& M Developments $L t d{ }^{128}$ and the clear statements of the Court of Appeal in Popyk v. Western Savings and Loan Association. ${ }^{129}$ In the former case, Belzil J. held that the burden was on the vendor to show that it would be inequitable for him to have to return the money. On appeal from Belzil J., this point was not mentioned by the Court of Appeal. However, in Popyk, the Court of Appeal made it very clear that the onus is on the purchaser seeking relief to show that it will be unconscionable for the vendor to retain the money paid. The Popyk case was followed in World Land Ltd. v. Daon Development Corporation Ltd. ${ }^{130}$ In Coronado Developments Ltd. v. W.E.D. Developments Ltd., ${ }^{131}$ Cawsey J. reviewed the authorities and confirmed the approach taken by the Court of Appeal in Popyk, namely that, "the burden of proving unconscionability is on the defaulting party."

\section{B. UNCONSCIONABLE}

Cawsey J. proceeded to review the question of what is "unconscionable" and set out some of the factors that the court may consider in determining whether it is in the circumstances unconscionable for the vendor to keep the money paid (in that case $\$ 280,000$ ):

1. The evidence satisfied me that at the date of this Agreement for Sale the prospects for the sale of developed residential lots in the Redwater area were excellent and the respondents could have made a substantial amount of money if they would have been able to develop and sell all of the lots.

125. March Bros. v. Banton (1911) 45 S.C.R. 338 at 343 (tender made and refused); Kilmer v. B.C. Orchard Lands Co. [1913] A.C. 319 at 322 (P.C.) (purchaser paid amount into Court); Drinkle v. Steedman (1915) 9 W.W.R. 1146 at 1147 (P.C.) (amount due tendered and refused twice); Woels v. Mashinter [1976] 5 W.W.R. 79 at 93-94 (money held in trust, vendor notified and attempts made to close); Schmitt v. Terrace Corporation (Construction) Ltd. (1981) 30 A.R. 518 at 526 (Q.B.)(funds tendered and refused); World Land Ltd. v. Daon Development Corp. Ltd. [1982] 4 W.W.R. 577 at 590 (money tendered and refused); City of Edmonton v. A. \& M. Developments Ltd. (1980) 17 R.P.R. 304 at 310 (S.C.) (tender made and offer to remedy delay).

126. Moore and MacDowall v. Stewart (1914) 7 W.W.R. 991 at 993 (Sask. S.C.) (purchasers not prepared to remedy default); Hole v. Wilson (1911) 16 W.L.R. 352 at 355 (Sask. S.C. en banc) (purchaser refused to make any payment); Zimmer v. Karst (1910) 15 W.L.R. 58 at 65 (Sask. S.C.) (purchasers refused to make payment); Stockloser v. Johnson [1954] 2 W.L.R. 439 at 441 (purchaser financially unable or unwilling to complete the contracts); Popyk v. Western Savings \& Loan Association (1969) 67 W.W.R. 684 at 688 (Alta. A.D.) (no tender - purchaser's ill health); Coronado Developments Ltd v. W.E.D. Developments Ltd. (1982) 24 A.L.R. (2d) 34, 42 A.R. 283 (Alta. Q.B.) (purchaser unable to raise money and not requesting specific performance).

127. (1981) 19 Alta. L. Rev. 192, 203.

128. (1980) 17 R.P.R. 304, 312.

129. (1969) 67 W.W.R. 684, 692, 3 D.L.R. (3d) 511 (Alta. A.D.).

130. [1982] 4 W.W.R. 577 at 607.8 .

131. Supra n.113 
2. That because of a downturn in the economy there is a surplus of residential lots in Redwater. The lots have gone down in value according to the evidence of Lochansky, and according to the evidence of Paine the lots are not now marketable.

3. The respondent is not asking for specific performance and the respondent has not been able to raise any money to make the payments required under the agreement.

4. That the respondents were engaged in a speculative venture, or to put it in the words of counsel for the applicant, the respondents entered into the agreement to turn a profit and they have gambled on an unsuccessful venture and they have lost.

No explanation was offered by the purchaser for failing to tender the balance of the purchase price.

His Lordship continued:

The plaintiff in this action has received $\$ 250,000.00$ on a total contract price of $\$ 940,960.00$ or $26 \%$ of the total purchase price. I am not including the amount paid for interest because this was justly due and owing under the Agreement for Sale. The defendants defaulted in making the payment of $\$ 275,000.00$ due on the 1st of August, 1981 and the subsequent payment due on the 1st of May; 1982. The plaintiff has determined and cancelled the Agreement for Sale and the defendants have made no offer to make the payments current. The plaintiff has incurred considerable expenses and lost considerable income because of his agreement with the defendants. He paid Williams a finder fee of $\$ 21,000.00$, he loaned the defendant company $\$ 93,000.00$, he has lost interest of $\$ 60,000.00$ and he had also lost interest on the money which should have been paid in May of 1982 , amounting to $\$ 9,000.00$. The total amount which has been lost by the plaintiff is $\$ 183,000.00$.

In addition, by entering into the Agreement for Sale with the defendants he has lost the opportunity to sell the land to some other purchaser when the market was more buoyant. He has been required to pay the taxes on the land which he would not have been required to do if the agreement had been carried out by the defendants. He has lost the interest he would have received if the contract would have gone to maturity. He has been unable to pay his own mortgage on the land and it is in the process of foreclosure. As a result of this judgment he will have a subdivided parcel of land which will attract higher taxes than the land sold to the defendant. His losses as a result of this transaction would clearly exceed the sum of $\$ 280,000.00$ and I do not consider it unconscionable for the plaintiff to retain all amounts paid to it by the defendant. I am therefore rejecting the defendants' application for relief against forfeiture.

In Tymo v. Wild Rose Properties Ltd. ${ }^{132}$ Purvis J. referred to City of Edmonton v. A \& M Developments Ltd. ${ }^{133}$ and World Land Ltd. v. Daon Development Corporation Ltd. ${ }^{134} \mathrm{He}$ noted that in the first case the value of the land had gone from $\$ 771,012$ at the date of the agreement for sale to $\$ 5,100,000$ at the date of trial, while in the second case, values had gone from $\$ 95,000$ per acre to $\$ 400,000$ per acre. His Lordship concluded that in those cases, the vendor was compensated for any loss by the increase in value of the land. Purvis J. continued:

In the within case, any change in the market value of the land after the date of its purchase is of the utmost importance to me in reaching a decision as to whether or not I should exercise my discretion to grant relief against the penalty imposed against by the agreement. Unfortunately, there is a dearth of probative evidence in the material submitted as to the market value of the land at the date of sale and subsequent thereto.

He accordingly directed a trial of the issue of relief from forfeiture.

Other items that may be considered in assessing whether or not it will be unconscionable for the vendor to retain the money will include: what interest rates could have been obtained for the payments if they had been made on time as anticipated by the agreement, and what payments may have been made on prior agreements for sale. Where such payments were made by the vendor despite not receiving money from the purchaser, what was the vendor's cost of borrowing money to do this?

132. Supra n.22.

133. Supra n.128.

134. Supran.130. 
In MacDonald v. Paterson Park Ltd, ${ }^{135}$ Funduk M.C. had to consider whether it may, in the context of a summary judgement application, be unconscionable for the Plaintiff's to retain all the purchase money paid. ${ }^{136}$ He continued:

The question [as to whether retention of the purchase money may be unconscionable] could be answered by comparing what the plaintiffs (vendors) would have received if the defendant (purchaser) had performed all its obligations under the agreement with what the plaintiffs will receive if they are allowed to both retain all the purchase money paid and get the land back. If what the plaintiffs 'receive', in economic terms, by retaining the purchase money and getting the land back does not exceed what they would have received, in economic terms, if the defendant had fully performed its obligations, it is not possible to say that it may be unconscionable for the plaintiffs to retain the purchase money.

In that case, the amount still owing when the agreement was determined was about $\$ 308,000$ and the market value of the land was $\$ 277,000$ (forced sale, cash $\$ 180,000$ ). Funduk M.C. followed Coronado Developments Ltd. ${ }^{137}$ and held that on the evidence before him it was not possible to say that it may be unconscionable for the plaintiffs to retain all the purchase money paid, since they already faced a loss. By comparison, in Sigma Lands Ltd. v. Felgua Investments Ltd., ${ }^{138}$ Funduk M.C. adjourned the application for a declaration that the purchase monies paid be forfeited in order to allow the defendants to consider their position and take whatever steps they might be advised. Although he had granted a declaration that the agreement for sale had been determined, in that case the evidence of land value showed that the land was worth $\$ 362,000$ forced sale for cash to $\$ 482,000$ market value, while the amount owing would only be about $\$ 350,000$. While the Master did not wish to imply that the purchasers might be successful in obtaining any relief, his sole concern was whether their lawyers realized what was happening.

\section{CONCLUSION}

Due to economic conditions, the last two years have not seen the rapid development of the remedy of extra-judicial determination that might have been anticipated. In many cases, the value of land has fallen dramatically and vendors prefer to sue for specific performance in an attempt to recover the full contract price. The land will be sold for what it will fetch, either to a third party or to the vendor, ${ }^{139}$ with the possibility of a deficiency judgment if the value of the land is less than the amount owing on the agreement. ${ }^{140}$ In other cases, vendors will determine the agreement for sale, preferring to forego any deficiency claim and to take the land back in

135. Supra n.110

136. See cases referred to at n.3-6, supra.

137. Supra n.113.

138. Unreported, 21 January 1983, Q.B. 8203-29278.

139. On the ability of the vendor to purchase the property, crediting the purchase price against the amount owing on the agreement for sale and obtaining judgment for the balance, see the decision of Funduk M.C. in Lennie v. LD.M. Holdings Ltd. (1982) 40 A.R. 87; affd. on appeal by Legg J., 13 December, 1982, where the principles of Trusts \& Guaranty Co. Ltd. v. Rice[1924] 2 W.W.R. 691 (Alta. S.C.A.D.) were applied to a specific performance action on an agreement for sale. Followed in North West Trust Co. v. M.C.C. Development Ltd, unreported 18 March 1983, Q.B. 8203-03823 (Quinn M.C.).

140. The vendor must remember s.40(2) of the Law of Property Act, R.S.A. 1980, c.L-8, which prevents proceedings to enforce a judgment on the personal covenant until after sale of the land, and then only for the deficiency. 
satisfaction of the balance outstanding. ${ }^{141}$ Other vendors may perhaps exercise their contractual rights in order to bring pressure on the purchasers faster than they could through the normal specific performance action.

Whatever the reasons, it is clear that lawyers will have to explain carefully to their clients, both vendors and purchasers, the rights and obligations their clients have under the contract and in light of judicial authority. A vendor must be advised of the possibility of the purchaser obtaining the return of some or all of the money paid under the agreement. A purchaser may need advice on his ability to accept the determination and "walk away" from the land, thus avoiding a potential deficiency judgment, or alternatively on his ability to claim a return of the money paid.

Once the decision to determine has been reached, it is still as essential as ever that the procedure be followed correctly, otherwise the advantages of the extra-judicial process rapidly evaporate, leaving a complex, contested lawsuit from which there may be no easy escape.

141. Davidson v. Sharpe (1920) 60 S.C.R. 72 at 85 . Costs: - where the agreement for sale provides for the defaulting purchaser to pay costs on a solicitor and client basis, such costs cannot be recovered by the vendor if he determines the agreement, as the contractual foundation for such costs ceases to exist: Vladimer Holdings Co. Ltd. v. 203136 Alberta Ltd. (1982) 39 A.R. 104, per Funduk M.C.; Sigma Lands Ltd. v. Felgua Investments Ltd., unreported, 21 January 1983, Q.B. 8203-29278, per Funduk M.C.. However, the successful vendor will be entitled to costs pursuant to the Rules of Court, as these are separate from any agreement: id. 